\title{
FAKTOR-FAKTOR YANG MEMPENGARUHI PENGGUNAAN KONTRASEPSI MODERN OLEH WUS KAWIN PADA LIMA PROVINSI DI KTI (NTT, MALUKU, MALUKU UTARA, PAPUA, DAN PAPUA BARAT) TAHUN 2017
}

\author{
Analisis Data SDKI 2017
}

\author{
Wiranto Yainahu1, Waris Marsisno² \\ ${ }^{1}$ Politeknik Statistika STIS \\ 2 Politeknik Statistika STIS \\ Jl. Jerbus, RT 005/RW 003, Kel. Tanah Tinggi Barat, Kec. Ternate Selatan, Kota Ternate, Maluku Utara \\ E-mail: 111710058@stis.ac.id
}

\begin{abstract}
ABSTRAK
Laju pertumbuhan penduduk yang tinggi serta penduduk yang semakin padat dapat mengakibatkan berbabagai masalah lain seperti jaminan kesejahteraan yang tidak dapat terlaksana secara optimal. Sehingga pemerintah mengeluarkan kebijakan untuk mengatasi masalah kependudukan salah satunya adalah program KB (Keluarga Berencana) dengan penggunaan kontrasepsi modern. Namun, partisipasi penggunaan kontrasepsi modern yang masih belum merata menjadi masalah lain. Seperti di wilayah KTI (Kawasan Timur Indonesia ) 10 dari 17 provinsi di KTI dalam penggunaan kontrasepsi modernnya masih berada di bawah rata-rata Nasional. Padahal pemerintah telah mengeluarkan kebijakan pemberian kontrasepsi gratis sejak tahun 2011 terhadap wilayah dengan TFR tinggi dan penggunaan kontrasepsi rendah. Oleh karena itu, penelitian ini bertujuan unutuk mengetahui gambaran dan variabel yang signifikan mempengaruhi penggunaan kontrasepsi modern wanita usia subur kawin pada lima provinsi di KTI tahun 2017, yaitu Nusa Tenggara Timur, Maluku, Maluku Utara, Papua, dan Papua Barat. Hasil regresi logistik biner diperoleh wanita dengan umur 25 sampai 34 tahun, jumlah anak hidup lebih dari dua, menginginkan jumlah anak maksimal dua anak, pendidikan SD sampai SMP, bekerja, pendidikan suami SD sampai SMP, suami yang bekerja, dan mendapat kunjungan petugas KB memiliki hubungan yang signifikan dengan penggunaan kontrasepsi modern. Peran petugas KB lebih dioptimalkan dalam menjaring calon pengguna kontrasepsi modern.
\end{abstract}

Kata kunci: Keluarga Berencana, Kontrasepsi modern, regresi logistik biner

\section{ABSTRACT}

High population growth rates and increasingly dense populations can lead to various other problems such as welfare guarantees that cannot be carried out optimally. So the government issued a policy to address population problems, one of which was a family planning program with the use of modern contraception. However, participation in the use of modern contraception which is still uneven becomes another problem. As in the KTI region (Eastern Indonesia) 10 out of 17 provinces in KTI in their use of modern contraception are still below the national average. Even though the government has issued a policy of providing free contraception since 2011 to regions with high TFR and low contraceptive use. Therefore, this study aims to determine the images and variables that significantly influence the use of modern contraception for women of childbearing age in the five provinces of Eastern Indonesia in 2017, namely East Nusa Tenggara, Maluku, North Maluku, Papua, and West Papua. Binary logistic regression results obtained by women aged 25 to 34 years, the number of children living more than two, want the maximum number of children of two children, education from elementary to junior high, working, education from elementary to junior high school husband, working husband, and having family planning staff visit has significant relationship with the use of modern contraception. The role of family planning officers is more optimized in recruiting potential users of modern contraception.

\section{Keywords: family planning, modern contraception, binary logistic regression}

\section{PENDAHULUAN}

Latar belakang dari penelitian ini adalah berdasarkan hasil SUPAS (survei penduduk antar sensus) yang dilakukan oleh BPS pada tahun 2015 jumlah penduduk Indonesia sebanyak 255,18 juta jiwa (BPS, 2016) , menjadikan Indonesia sebagai negara dengan jumlah penduduk terbesar 
keempat di dunia. Laju pertumbuhan yang tinggi merupakan salah satu faktor penyebab besarnya jumlah penduduk di Indonesia. Meskipun sejak tahun 2010-2015 laju pertumbuhan penduduk mengalami penurunan dari 1,49 persen menjadi 1,43 persen, tetapi masih saja belum mampu mencapai terget dari Rencana Pembangunan Jangka Menengah Nasional (RPJMN) 2015 yaitu sebesar 1,38 persen. Penduduk yang selalu mengalami pertambahan tiap tahunnya dapat menimbulkan berbagai masalah seperti penambahan beban bagi negara untuk memberikan energi dan pangan serta jaminan kesehjateraan lalu muncul juga masalah lain seperti kepadatan penduduk karena dengan penambahan jumlah penduduk tidak disertai dengan bertambahnya luas negara Indonesia. Sehingga masalah laju pertumbuhan penduduk ini merupakan masalah yang serius untuk ditangani. Banyak hal dapat mengakibatkan bertambahnya jumlah penduduk seperti, Total Fertility Rate (TFR), migrasi masuk, serta kematian. TFR sendiri adalah faktor utama dari laju pertumbuhan penduduk yang tinggi. Dari hasil publikasi Survei Demografi dan Kesehatan Indonesia (SDKI) tahun 2017 menyatakan bahwa TFR Indonesia berada di angka 2,4, turun dari data SDKI tahun 2012 yang sebesar 2,6. Meskipun mengalami penurun tetap saja TFR Indonesia belum mencapai target RPJMN 2017 yang ditargetkan berada di angka 2,33 anak (bps, 2018). Sehingga dalam rangka untuk menekan angka TFR maka pemerintah melalui Badan Kependudukan dan Keluarga Berencana Nasional (BKKBN) melakukan kebijakan Keluarga Berencana (KB).

KB merupakan program yang dilakukan oleh pasangan kawin untuk mejarangkan ataupun membatasi jumlah anak yang dimiliki (BKKBN, 2015). Di Indonesia sendiri program KB sudah dilaksanakan mulai tahun 1970 dan terbukti efektif menurunkan angka TFR dari awalnya 5,61 menjadi 4,68 pada tahun 1980 lalu turun lagi menjadi 3,3 tapi mulai tahun 1997 TFR cenderung tidak mengalami perubahan yang singnifiakn di angka 2,3 sampai 2,6 di tahun 2017. Dalam pelaksanaan program KB, BKKBN mengendalikan angka TFR dengan metode kontrasepsi. Penggunaan kontrasepsi diklasifikasikan menjadi dua kelompok kontrasepsi modern dan tradisional. Kotrasepsepsi modern terdiri menjadi modern terdiri dari metode operasi wanita (MOW) atau sterilisasi wanita, metode operasi pria (MOP) atau sterilisasi pria, pil, IUD, suntik KB, susuk KB, kondom, diafragma, metode amenore laktasi (MAL), dan kontrasepsi darurat. Sementara kontrasepsi tradisional yaitu pantang berkala, senggama terputus, dan alat atau cara KB lainnya tradisional lainnya. Dengan banyaknya pemilihan kontrasepsi mulai dari yang digunakan pria atau wanita diharapkan metode kontrasepsi dapat menekan angka TFR. Dalam penggunaan kontrasepsi, Wanita Usia Subur (WUS) kawin memiliki pilihan kontrasepsi yang lebih bervariasi karena WUS kawin merupakan target dari program KB (BKKBN, 2016). Data SDKI 2017 menyatakan bahwa WUS kawin yang menggunakan paling tidak satu jenis KB sebesar 63,6 persen naik dari data SDKI 2012 yang bernilai 61,9. Hal ini terjadi karena penggunaan kontrasepsi tradisional naik dari tahun 2012 yang bernilai 4 persen menjadi 6,4 persen persen ditahun 2017. Namun pada kontrasepsi modern malah terjadi penurunan dari tahun 2012 yaitu 57,9 persen menjadi 57,2 meskipun penurunan yang terjadi hanya sedikit hanya 0,7 persen. Tetapi target RPJMN 2017 yang sebesar 60,9 masih saja belum tercapai.Padahal juga kontrasepsi modern lebih efektif dalam mencegah kehamilan daripada kontrasepsi tradisional (Bradley et al., 2012).

Penggunaan kontrasepsi sendiri dipengaruhi oleh banyak faktor Bertrand (1980) kontrasepsi dipengaruhi oleh tiga faktor yaitu faktor sosidemografi, faktor sosial psikologi, dan faktor pelayan KB itu sendiri. Pemilihan alat kontrasepsi yang digunakan juga berdasarkan kenyamanan serta kemudahan akses untuk mendapatkannya. Di Indonesia sendiri berdasarkan data SDKI 2017 WUS kawin yang memakai alat kontrasepsi modern di perkotaan sebesar 55,0 persen turun dari tauhun 2012 yaitu 57 persen dan malah WUS kawin di perdesaan yang mengalami kenaikan di tahun 2012 dari 58,7 persen menjadi 59,2 persen di tahun 2017. Masyarakat Indonesia yang majemuk yang memilki banyak perbedaan sosial dan demografi menjadi salah satu kaitan dalam pemilihan metode kontrasepsi. Selain itu kesenjangan wilayahwilayah di Indonesia juga merupakan faktor rendahnya partispasi WUS kawin terhadap pemakain kontrasepsi modern. Susahnya akses mendapatakan alat kontrasepsi modern serta fasilitas kesehatan yang tidak memadai menambah kondisi lain yang membuat program KB tidak dapat mencapai target RPJMN. Penyebab belum tercapainya target RJMN mengenai penggunaan kontrasepsi modern oleh WUS kawin di Indonesia salah satunya karena terjadi kesenjangaan di 
antar wilayah. Berdasarkan data SDKI 201710 dari 17 wilayah di kawasan Timur Indonesia (KTI) yang menggunakan alat kontrasepsi modern yang masih dibawah rata-rata nasional Sedangkan di Kawasan Barat Indonesia(KBI) hanya 5 provinsi memiliki WUS kawin yang menggunakan alat kontrasepsi modern yang masih dibawah rata-rata nasional. Hal ini menunjukan masih belum meratanya penggunaan WUS kawin pada wilayah-wilayah di Indonesia.

Belum meratanya penggunaan kontrasepsi modern oleh WUS kawin di Indonesia sebenarnya sudah lama menjadi perhatian pemerintah. Pada saat ini Pemerintah menyediakan secara gratis tiga jenis alokon di seluruh wilayah Indonesia, yaitu kondom, Alat Kontrasepsi Dalam Rahim (AKDR), dan susuk KB. Terdapat 7 provinsi yang menyediakan alokon lainnya juga secara gratis, yaitu Aceh, Nusa Tenggara Barat, Nusa Tenggara Timur, Maluku, Maluku Utara, Papua, dan Papua Barat. Di provinsi lain, selain kondom, AKDR, dan susuk KB, jenis alokon lainnya hanya tersedia secara gratis bagi masyarakat miskin (Keluarga Pra Sejahtera dan Keluarga Sejahtera 1) (BKKBN, 2018). Hal ini berarti pemerintah telah memberikan alat kontrasepsi modern secara gratis bagi wilayah di Indonesia yang dianggap memiliki angka TFR yang tinggi sehingga diharapkan denggan penggunaan alat kontrasepsi modern dapat menekan angka kelahiran.Secara umum dapat disimpulkan bahwa Provinsi Aceh, Nusa Tenggara Barat, Nusa Tenggara Timur, Maluku, Maluku Utara, Papua, dan Papua Barat merupakan wilayah yang masih kurang dalam partisipasi penggunaan alat kontrasepsi modern padahal pemerintah telah menggeluarkan undang-undang Sesuai dengan UU RI Nomor 36 Tahun 2009 tentang Kesehatan, pada pasal 78 pada ayat 2 memeiliki makna bahwa pemerintah menjamin pemberian alat kontrasepsi modern secara gratis di ketujuh provinsi tersebut. Dan yang menjadi perhatian 6 dari 7 provinsi terkait merupaka provinsi di wilayah KTI.

Laju pertumbuhan serta TFR yang masih belum mencapai target dari RPJMN merupakan permasalahan penduduk yang harus ditangani. Dengan luas wilayah yang tetap permasalahan penduduk dapat menyebabkan banyak masalah-masalah lainnya. Pemerintah melalui BKKBN yang melaksanakan program keluarga berencana merupakan salah satu upaya nyata dalam mengendalikan angka kelahiran. Dan salah satu dari program keluarga berencana adalah metode kontrasepsi.

Kontrasepsi itu sendiri dibedakan menjadi dua kontrasepsi modern dan kontrasepsi tradisional. Kontrasepsi modern sendiri merupakan kontrasepsi yang dapat dikontrol oleh pemerintah dalam program KB karena dianggap ledih efektif dalam mencegah kehamilan. Wanita yang menggunakan alat kontrasepsi tradisional dengan tujuan untuk mengendalikan kelahiran di indikasikan karena alat kontrasepsi modern belum diperoleh (Bradley et al., 2012).

Penelitian yang dilakukan oleh Ekariano dan Novita (2018) menjelaskan bahwa faktor yang mempengaruhi penggunaan alat kontrasepsi adalah jumlah anak yang dilahirkan. Dan dari penilitian yang dilakukan oleh Aryati et al. (2019) menunjukan bahwa WUS kawin lebih banyak menggunakan kontrasepsi modern untuk mencegah kehamilan dengan metode suntik sebagai alternatifnya kemudian faktor yang berpengaruh adalah jenis kelamin anak yang dilahirkan.

Kontrasepsi modern yang lebih efektif dalam mencegah kehamilan daripada kontrasepsi tradisional membuat pemerintah semakin gencar dalam membuat kebijakan-kebijakan agar WUS kawin yang memakai kontrasepsi modern dalam alternatif mengotrol kehamilan semakin meningkat. Seperti yang diatur dalam UU RI Nomor 36 Tahun 2009 ayat 1 Menjelaskan bahwa pemerintah memberikan Alat dan obat kontrasepsi (Alokon) secara gratis kepada seluruh provinsi di Indonesia yaitu kondom, Alat Kontrasepsi Dalam Rahim (AKDR), dan susuk KB. Hal ini dilakukan pemerintah dengan harapan angka TFR di Indonesia dapat lebih ditekan.

Adapun pemilihan wilayah kawasan timur Indonesia karena masih kurangnya penelitian yang dilakukan di daerah sana. Batasan wilayah yang digunakan adalah KTI mencakup NTT, Maluku, Maluku Utara, Papua, dan Papua Barat berdasarkan Perkba BKKBN Nomor 78/PER/E3/2011, mengenai daerah terpencil, tertinggal, dan perbatasan, serta data SDKI 2017 menunjukan bahwa TFR di daerah KTI masih tinggi masih berada di atas rata-rata TFR nasional. Dimana TFR untuk masing-masing provinsi yaitu 3,4, 3,3 ,2,9,3,2, dan 3,3. Sedangkan rata-rata nasional 2,4 anak (BPS, 2018). Hal yang sama juga terjadi pada kontribusi pemakain alat kontrasepsi modern oleh WUS kawin sebagai pengontrol kehamilan yang dianggap efektif untuk wilayah KTI sendiri masih berada di bawah rata-rata nasional bahkan berada di urutan-urutan terbawah dengan 
Provinsi Papua dan Papua Barat sebagai provinsi yang sama-sama memiliki nilai 35,9 persen sedangkan rata-rata nasional 57,2 persen. Padahal sejak 2009 pemerintah telah mengeluarkan UU pemberian Alakon gratis kepada 5 provinsi KTI diatas. Hal ini yang menjadikan penelitian ini sangat menarik untuk diteliti. Peniltian ini bertujuan untuk mengetahui gambaran, faktor, serta kecenderungan WUS kawin di KTI dalam menggunakan kontrasepsi modern.

Dalam penelitian yang berjudul "Socio-Economic and Demographic Factors Affecting Contraceptive use in Malawi", Palamuleni (2013) menggunakan metode analisis regresi logistik bivariate dan multivariate untuk membangun hubungan antara variabel sosial ekonomi dengan penggunaan kontrasepsi. Data diperoleh dari Survei Demografi dan Kesehatan Malawi yang berorientasi pada wanita yang sudah menikah. Hasilnya menunjukan bahwa faktor penentu penggunaan kontrasepsi modern adalah usia, persetujuan respendonden dengan pasangan mengenai keluarga berencana, diskusi dengan pasangan menegenai keluarga berencana, status pekerjaan, pendidikan, dan kunjungan ke pusat kesehatan.Penilitian yang dilakukan oleh Manortey dan Lotsu (2017) yang berjudul "Factors Affecting Contraceptive Use among Reproductive Aged Women: A Case Study in Worawora Township, Ghana", dengan tujuan untuk mengetahui faktorfaktor yang mempengrauhi penggunaan kontrasepsi modern oleh wanita berusia subur di Ghana. Sebanyak 390 wanita berusia 15 sampai 49 tahun dijadikan sebagai sampel. Analisis yang digunakan adalah analisis regresi logistik bivariate dan multivariat. Hasil yang diperoleh dalam penelitian adalah usia, jumlah anak, jumlah anggota dalam rumah tangga, pekerjaan, status perkawinan, tingkat pendidikan pasangan, dan diskusi dengan pasangan memilikki pengaruh yang seignikan terhadap penggunaan kontrasepsi modern. Wanita yang berada dalam kelompok umur 35 sampai 40 tahun berpeluang empat kali lebih besar dalam menggunakan kontrasepsi modern daripada kelompok wanita yang lebih muda.

\section{METODE}

Menurut Shaw (2010), Keluarga berencana memungkinkan individu dan pasangan untuk mengantisipasi dan mencapai jumlah anak yang diinginkan serta jarak dan waktu kelahiran mereka. Hal ini dicapai melalui penggunaan metode kotrasepsi dan pengobatan infertilitas sukarela. Kemampuan seorang wanita untukmengatur jarak dan membatasi kehamilannya memiliki dampak langsung pada kesehatan dan kesejahteraannya serta pada hasil setiap kehamilan. Tujuan program KB adalah agar pasangan atau perseorangan mampu menentukan secara bebas dan responsible jumlah anak dan jarak kelahiran anak yang ingin mereka miliki. Selain itu, program KB berfungsi agar masyarakat mengetahui informasi lebih sehingga mampu menentukan pilihan dan memakai alat atau cara yang aman dan efektif (UN, 1995).

Hartanto (2004) Kontrasepsi berasal dari dua suku kata, yakni kata kontra dan konsepsi. Kontra berarti "melawan" atau "mencegah", dan konsepsi merupakan pertemuan antara sel telur yang matang dengan sperma yang mengakibatkan kehamilan. Tujuan dari penggunaan kontrasepsi adalah menghindari atau Mencegah terjadinya kehamilan yang disebabkan pertemuan antara sel telur dengan sel sperma. Berdasarkan uraian tersebut, maka yang membutuhkan penggunaan kontrasepsi merupakan pasangan yang aktif melakukan hubungan seks dan keduanya memiliki kesuburan normal namun tidak menghendaki kehamilan (Suratun et al., 2008). Menurut BKKBN (2011), kontrasepsi adalah obat atau alat untuk mencegah terjadinya konsepsi (kehamilan).

Jenis kontrasepsi dikelompokan menjadi dua,yaitu kontrasepsi modern dan kontrasepsi tradisional. Kontrasepsi modern terdiri dari metode operasi wanita (MOW) atau sterilisasi wanita, metode operasi pria (MOP) atau sterilisasi pria, pil, IUD, suntik KB, susuk KB, kondom, diafragma, metode amenore laktasi (MAL), dan kontrasepsi darurat. Kontrasepsi tradisional erdiri dari pantang berkala, sanggama terputus, dan alat/cara KB lainnya tradisional lainnya(BPS, 2018).

Dalam penelitian ini ruang lingkup mencakup variabel respons berupa data kategorik yang teridentifikasi dengan jenis alat kontrasepsi modern yang digunakan oleh wanita usia subur berstatus kawin yang berusia dari 15 sampai 49 tahun pada tahun 2017 dan memakai wilayah di kawasan timur Indonesia yang mencakup provinsi NTT, Maluku, Maluku Utara, Papua, dan Papua Barat. Data yang digunakan adalah data Survei Demografi dan Kesehatan Indonesia tahun 2017 
yang dilaksanakan oleh BPS, BKKBN dan Kemenkes. Adapun variabel respons yang digunakan dalam penelitian ini adalah WUS kawin yang tidak menggunakan kontrasepsi modern dan mengunakan kontrasepsi modern. Kemudian faktor-faktor yang diduga berpengaruh dalam penggunaan kontrasepsi modern WUS kawin adalah umur, jumlah anak hidup, jumlah anak ideal, daerah tempat tinggal, pendidikan, status bekerja, pendidikan suami, status bekerja, kunjungan petugas KB, dan indeks kekayaan.

Data yang digunakan dalam penelitian ini berasal dari data sekunder yang bersumber dari data Survei Demografi dan Kesehatan Indonesia (SDKI) tahun 2017. SDKI 2017 dilaksanakan oleh Badan Pusat Statistik (BPS),Badan Kependudukan dan Keluarga Berencana Nasional (BKKBN), dan Kementrian Kesehatan (Kemenkes). SDKI 2017 merupakan survei ke-delapan yang dilakukan di Indonesia, dimana sebelumnya telah dilaksanakan pada tahun 1987, 1991, 1994, 1997, 2002, 2003, 2007, dan 2012. Kegiatan SDKI 2017 dibiayai oleh Pemerintah Indonesia. Dalam teknis/pelaksanaannya, Pemerintah Indonesia dibantu oleh Inner City Fund (ICF) International melalui proyek Demographic and Health Surveys (DHS) Program, yaitu program United States Agency for International Development (USAID) yang menyediakan dana dan bantuan teknis dalam pelaksanaan survei kependudukan dan kesehatan di banyak negara. SDKI 2017 menyediakan gambaran menyeluruh tentang kondisi terkini mengenai kependudukan, keluarga berencana (KB), kesehatan reproduksi, dan kesehatan ibu dan anak di Indonesia. Tujuan utama SDKI 2017 adalah menyediakan estimasi terbaru indikator demografi dan kesehatan. Target responden SDKI 2017 adalah wanita umur 15-49 tahun, pria kawin/hidup bersama umur 15-54 tahun, dan remaja pria berstatus belum kawin umur 15-24 tahun Pada tahun 2017. Prosedur pemilihan sampel dalam penelitian ini yaitu pertama-tama sampel WUS yang berjumlah 49.627 wanita dipilih berdasarkan WUS yang berasal dari provinsi Nusa Tenggara Timur, Maluku, Maluiku Utara, Papua ,dan Papua Barat.Sehingga sampel yang diperoleh sampel sebesar 6.358 wanita. Dan kemudian dipilih lagi WUS yang berstatus kawin sehingga diperoleh sebanyak 4.555 wanita yang pada akhirnya dijadikan sebagai unit analisis.

Dalam penilitian ini metode analisis yang digunakan yaitu analisis deskriptif dan analisis inferensia dengan menggunakan regresi logistik biner. Analisis deskriptif dalam penelitian ini dilakukan untuk menjawab tujuan penelitian, yaitu gambaran umum mengenai karakteristik wanita usia subur berstatus kawin yang memilih menggunakan metode kontrasepsi kawin dalam mengendalikan kelahiran di lima provinsi KTI berdasarkan variabel bebasnya. Dalam penelitian ini analisis inferensia bertujuan untuk mengetahui faktor apa saja yang mempengaruhi WUS kawin di lima provinsi KTI dalam menggunakan kontrasepsi modern. Analisis inferensia juga digunakan untuk memeriksa apakah terdapat variabel bebas yang berpengaruh secara signifikan dengan variabel terikat.

\section{HASIL DAN PEMBAHASAN}

\section{Penggunaan kontrasepsi modern di lima provinsi KTI}

Gambaran penggunaan kontrasepsi modern di lima provinsi KTI, berdasarkan data SDKI tahun 2017 menyebutkan bahwa WUS kawin di wilayah KTI yang menggunakan kontrasepsi modern sebesar 38 persen. Sementara WUS kawin yang yang tidak menggunakan kontrasepsi modern adalah 62 persen. Data ini menunjukan masih rendahnya partisipasi penggunaan kontrasepsi modern oleh WUS kawin di lima provinsi KTI. Padahal, tingkat kefektifan kontrasepsi modern lebih tinggi daripada kontrasepsi yang lainnya dalam mengatur kelahiran anak (Kemenkes, 2013). 


\section{Sumber : SDKI 2017 (diolah)}

Gambar 1. Distribusi penggunaan kontrasepsi modern oleh WUS kawin di lima provinsi KTI tahun 2017

Persentase partisipasi penggunaan kontrasepsi modern oleh WUS kawin yang rendah mengedintifkasian terjadinya tingkat kelahiran serta laju pertumbuhan penduduk yang masih tinggi sehingga mengakibatkan penduduk yang semakin padat.

\section{Umur}

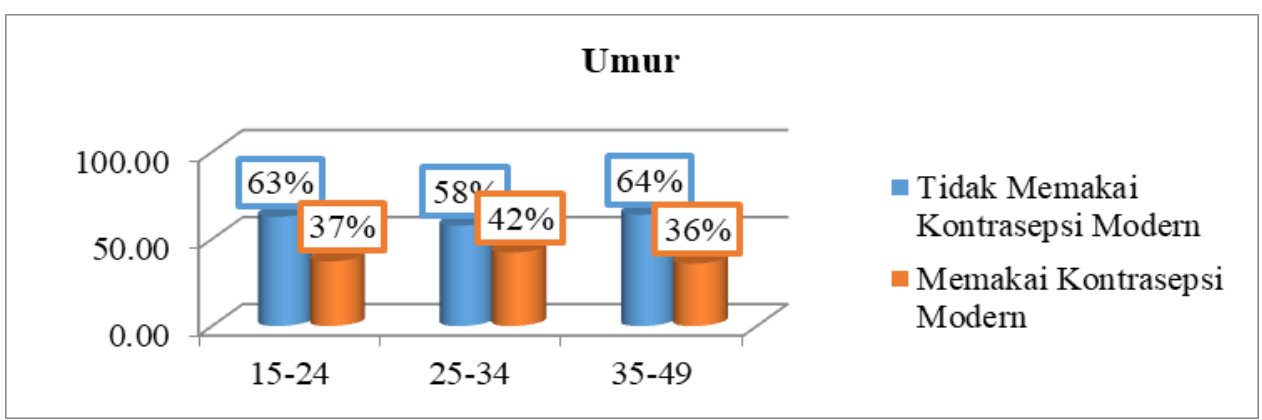

Sumber : SDKI 2017 (diolah)

Gambar 2. Persentase WUS kawin yang menggunakan kontrasepsi modern dan tidak menggunakan kontrasepsi modern berdasarkan variabel umur

Gambar 2 menunjukan bahwa WUS kawin yang tidak menggunakan kontrasepsi modern memiliki persentase yang lebih besar disetiap kelompok umur dibandingkan WUS kawin yang menggunakan kontrasepsi modern. Dengan masing-masing persentase WUS kawin yang berumur 15 sampai 24 tahun dan tidak menggunakan kontrasepsi modern adalah sebesar 63 persen, sedangkan WUS kawin yang berada dalam kelompok umur 15 sampai 24 tahun dan menggunakan kontrasepsi modern adalah sebesar 37 persen. Kemudian persentase WUS kawin yang berada dalam kelompok umur 25 sampai 34 tahun dan tidak menggunakan kontrasepsi modern adalah sebesar 58 persen, sedangakan WUS kawin yang berada dalam kelompok umur 25 sampai 34 tahun dan menggunakan kontrasepsi modern adalah sebesar 42 persen. Persenatase WUS kawin yang berumur 35 sampai 49 tahun dan tidak menggunakan kontrasepsi modern 64 persen, WUS kawin yang berumur 35 sampai 49 tahun dan menggunakan kontrasepsi modern adalah sebesar 36 persen. 


\section{Jumlah Anak Masih Hidup}

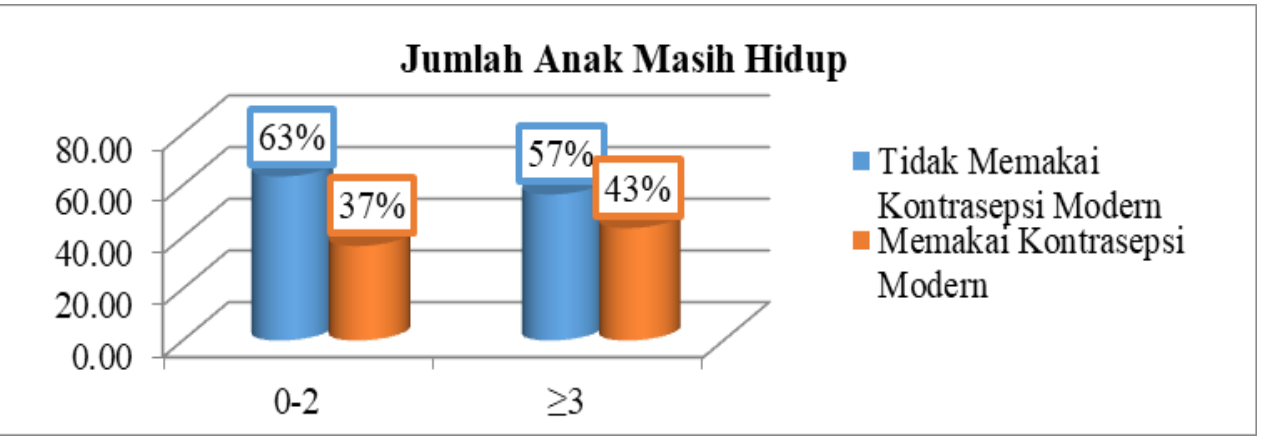

Sumber : SDKI 2017(diolah)

Gambar 3. Persentase WUS kawin yang menggunakan kontrasepsi modern dan tidak menggunakan kontrasepsi modern berdasarkan variabel jumlah $\mathrm{AMH}$

Gambar 3 dapat dilihat persentase WUS kawin yang tidak menggunakan kontrasepsi modern lebih besar dibandingkan WUS kawin yang menggunakan kontrasepsi modern baik yang memiliki jumlah AMH 0 sampai 2 anak maupun yang memiliki jumlah AMH lebih dari sama dengan 3 anak. Dengan persentase WUS kawin yang memiliki jumlah AMH 0 sampai 2 anak dan tidak menggunakan kontrasepsi modern yaitu sebesar 63 persen, sedangkan yang menggunakan kontrasepsi modern adalah sebesar 37 persen. Lalu persentase WUS kawin yang memiliki jumlah AMH lebih besar sama dengan 3 dan tidak menggunakan kontrasepsi modern sebesar 57 persen, angka ini lebih kecil dibandingkan WUS kawin yang memiliki jumlah AMH 0 sampai 2 anak juga tidak menggunkan kontrasepsi modern. Persentase WUS kawin yang memiliki jumlah AMH lebih besar sama dengan 3 dan menggunakan kontrasepsi modern adalah sebesar 43 persen, angka ini lebih besar dibandingkan dengan persentase WUS kawin yang memiliki jumlah AMH 0 sampai 2 anak dan menggunakan kontrasepsi modern.

\section{Jumlah Anak Ideal}

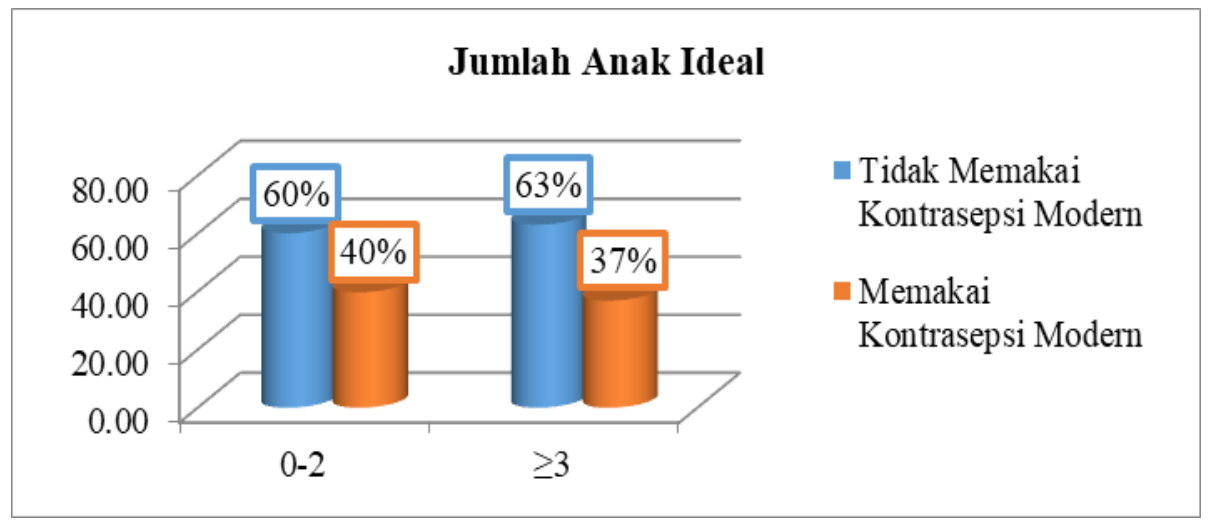

Sumber : SDKI 2017 (diolah)

Gambar 4. Persentase WUS kawin yang menggunakan kontrasepsi modern dan tidak menggunakan kontrasepsi modern berdasarkan variabel jumlah anak ideal

Persentase WUS kawin yang tidak menggunakan kontrasepsi modern memiliki persentase yang lebih besar daripada WUS kawin yang menggunakan kontrasepsi modern baik WUS kawin yang memiliki jumlah anak ideal sampai 2 anak maupun yang memiliki jumlah anak ideal lebih dari sama dengan 3 anak. Dengan persentase WUS kawin yang memiliki jumlah anak ideal 0 sampai 2 anak dan tidak menggunakan kontrasepsi memiliki persentase sebesar 60 persen, sedangkan yang menggunakan kontrasepsi modern adalah sebesar 40 persen. Lalu, persentase WUS kawin yang memiliki jumlah anak ideal lebih dari sama dengan 3 anak dan tidak menggunakan kontrasepsi modern sebesar 63 persen, angka ini lebih sedikit dibandingkan persentase WUS kawin yang memiliki jumlah anak ideal 0 sampai 2 anak. Persentase WUS kawin 
yang memiliki jumlah anak ideal 3 lebih dari sama dengan 3 anak dan menggunakan kontrasepsi yaitu sebesar 37 persen, angka ini lebih besar dibandingkan WUS kawin yang memiliki jumlah anak ideal 0 sampai 2 anak dan menggunakan kontrasepsi modern.

\section{Daerah Tempat Tinggal}

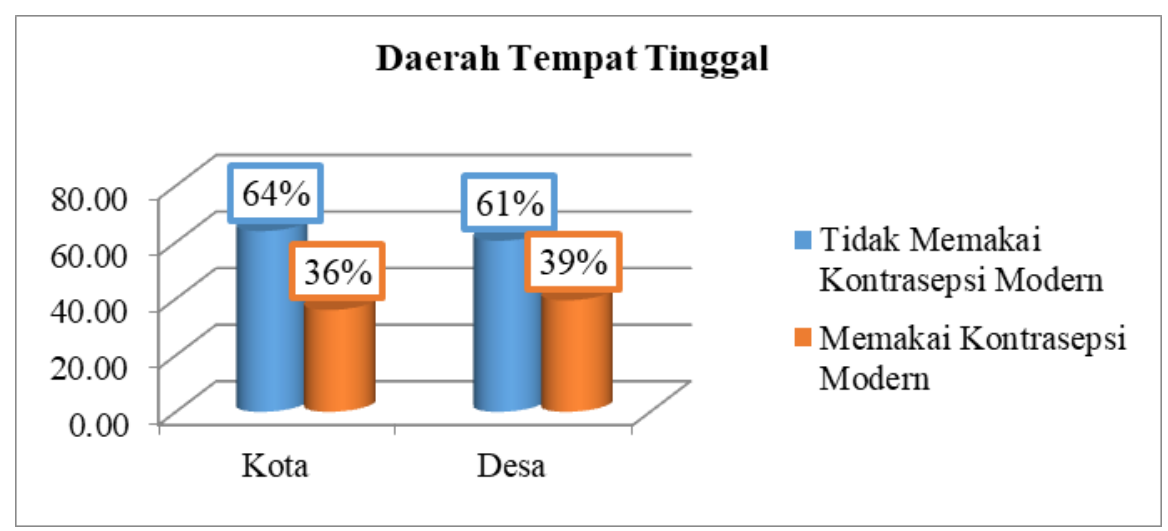

Sumber : SDKI 2017 (diolah)

Gambar 5. Persentase WUS kawin yang menggunakan kontrasepsi modern dan tidak menggunakan kontrasepsi modern berdasarkan variable daerah tempat tinggal

Persentase WUS yang tidak menggunkan kontrasepsi modern lebih besar dibandingkan persentase WUS kawin yang menggunakan kontrasepsi modern baik yang tinggal didaerah perkotaan maupun didaerah pedesaan. Persentase WUS kawin yang tinggal dikota dan tidak menggunakan kontrasepsi modern yaitu sebesar 64 persen, sedangkan yang menggunakan kontrasepsi modern adalah sebesar 36 persen. Lalu persentase WUS kawin yang tinggal didesa dan tidak menggunakan kontrasepsi modern adalah sebesar 61 persen, angka ini lebih kecil dibandingkan WUS kawin yang tinggal dikota dan tidak menggunakan kontrasepsi modern. Persentase WUS kawin yang tinggal didesa dan menngunakan kontrasepsi modern sebesar 39 persen, angka ini lebih besar dibandingkan WUS kawin yang tinggal dikota dan menggunkan kontrasepsi modern.

\section{Pendidikan}

Pada variabel pendidikan, dibagi menjadi tiga kategori yaitu tidak sekolah, lulus SD sampai SMP, dan lulus SMA keatas

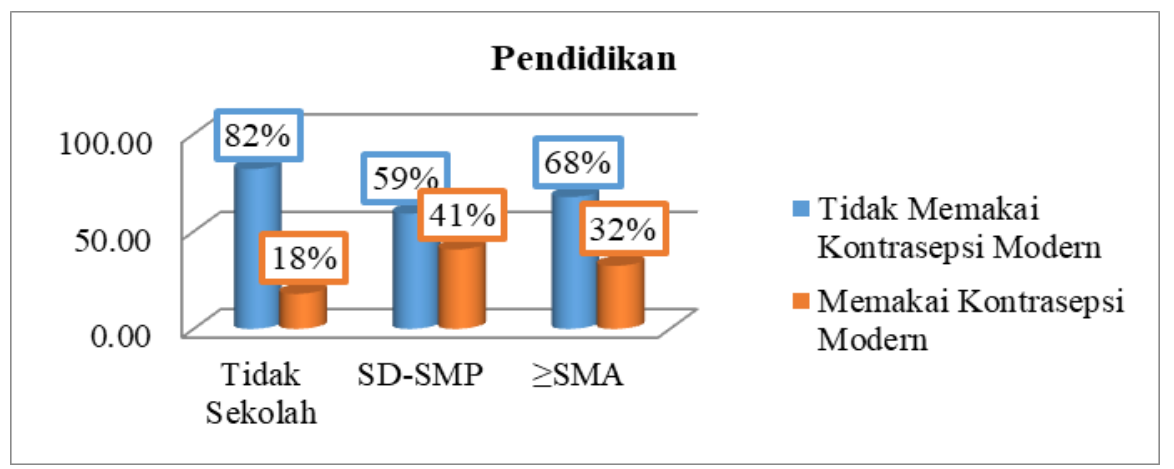

Sumber : SDKI 2017 (diolah)

Gambar 6. Persentase WUS kawin yang menggunakan kontrasepsi modern dan tidak menggunakan kontrasepsi modern berdasarkan variable pendidikan

Persentase WUS kawin yang tidak menggunakan kontrasepsi modern memiliki persentase yang lebih besar dibandingkan WUS kawin yang menggunakan kontrasepsi modern disetiap kategori pendidikan baik yang tidak sekolah, lulusan SD sampai SMP, dan lulusan SMA keatas. 
Persentase WUS kawin yang tidak sekolah dan tidak menggunakan kontrasepsi modern yaitu sebesar 82 persen, sedangkan WUS kawin yang tidak sekolah dan menggunakan kontrasepsi modern sebesar 18 persen. Lalu persentase WUS kawin yang lulus SD sampai SMP dan tidak menggunakan kontrasepsi modern adalah sebesar 59 persen, sedangkan WUS kawin yang lulus SD sampai SMP dan menggunakan kontrasepsi modern sebesar 41 persen. Persentase WUS kawin yang lulus SMA keatas dan tidak menggunakan kontrasepsi modern adalah sebesar 68 persen, sedangkan WUS kawin yang lulus SMA keatas dan menggunakan kontrasepsi modern sebesar 32 persen.

\section{Status Bekerja}

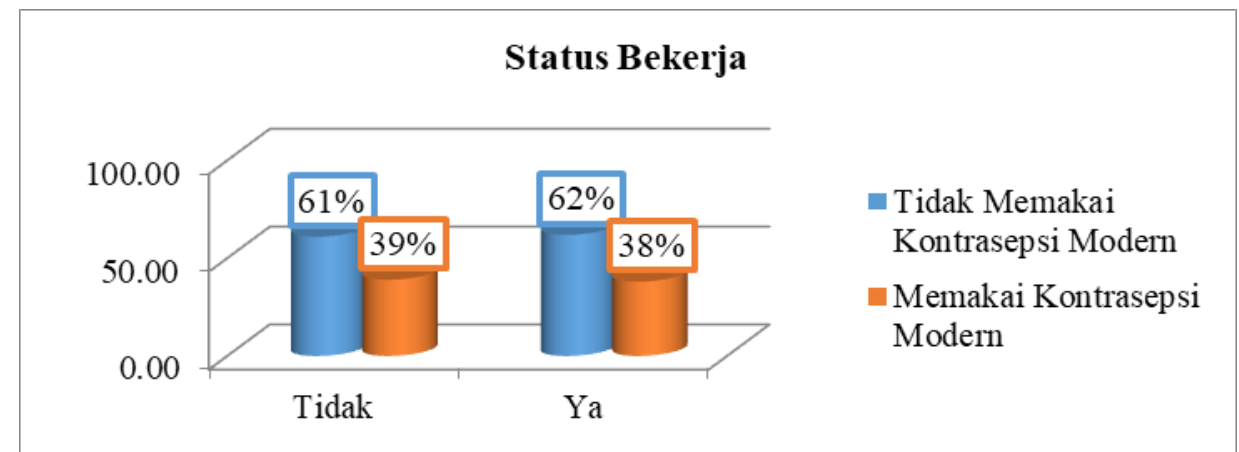

Sumber : SDKI 2017 (diolah)

Gambar 7. Persentase WUS kawin yang menggunakan kontrasepsi modern dan tidak menggunakan kontrasepsi modern berdasarkan variabel status bekerja

Persentase WUS yang tidak menggunkan kontrasepsi modern lebih besar dibandingkan persentase WUS kawin yang menggunakan kontrasepsi modern baik yang tidak bekerja maupun bekerja. Persentase WUS kawin yang tidak bekerja dan tidak menggunakan kontrasepsi modern yaitu sebesar 61 persen, sedangkan WUS kawin yang tidak bekerja dan menggunakan kontrasepsi modern adalah sebesar 39 persen. Lalu persentase WUS kawin yang bekerja dan tidak menggunakan kontrasepsi modern adalah sebesar 62 persen, angka ini lebih besar dibandingkan WUS kawin yang tidak bekerja dan tidak menggunakan kontrasepsi modern. Persentase WUS kawin yang bekerja dan mengunakan kontrasepsi modern sebesar 38 persen, angka ini lebih kecil dibandingkan WUS kawin yang tidak bekerja dan menggunkan kontrasepsi modern.

\section{Pendidikan Suami}

Pada variabel pendidikan suami, dibagi menjadi tiga kategori yaitu tidak sekolah, lulus SD sampai SMP, dan lulus SMA keatas

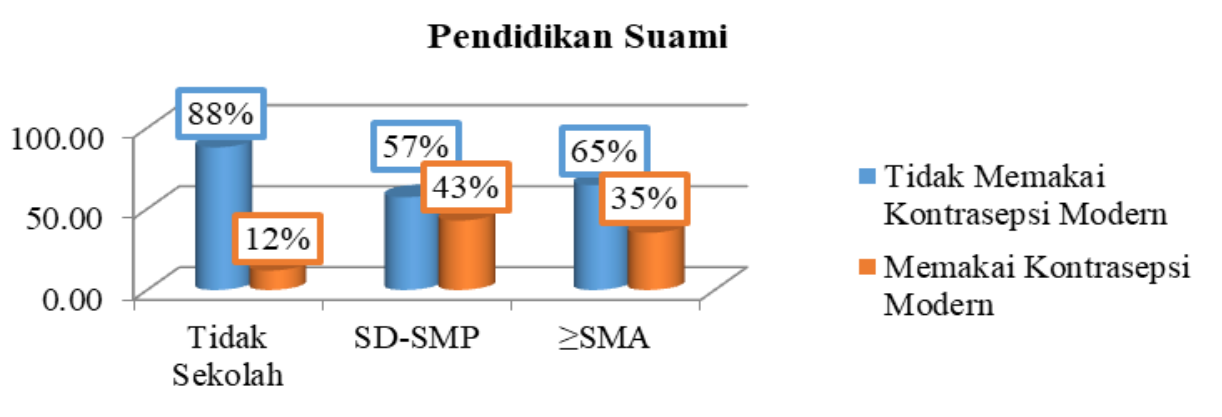

Sumber : SDKI 2017 (diolah)

Gambar 8. Persentase WUS kawin yang menggunakan kontrasepsi modern dan tidak menggunakan kontrasepsi modern berdasarkan variabel pendidikan suami

Persentase WUS kawin yang tidak menggunakan kontrasepsi modern memiliki persentase yang lebih besar dibandingkan WUS kawin yang menggunakan kontrasepsi modern disetiap 
kategori pendidikan suami baik suami yang tidak sekolah, lulusan SD sampai SMP, dan lulusan SMA keatas. Persentase WUS kawin yangmemiliki suami yang tidak sekolah dan tidak menggunakan kontrasepsi modern yaitu sebesar 88 persen, sedangkan WUS kawin yang memiliki suami tidak sekolah dan menggunakan kontrasepsi modern sebesar 12 persen. Lalu persentase WUS kawin yang suaminya lulus SD sampai SMP dan tidak menggunakan kontrasepsi modern adalah sebesar 57 persen, sedangkan WUS kawin yang suaminya lulus SD sampai SMP dan menggunakan kontrasepsi modern sebesar 43 persen. Persentase WUS kawin yang suaminya lulus SMA keatas dan tidak menggunakan kontrasepsi modern adalah sebesar 65 persen, sedangkan WUS kawin yang memiliki suami yang lulus SMA keatas dan menggunakan kontrasepsi modern sebesar 35 persen.

\section{Status Bekerja Suami}

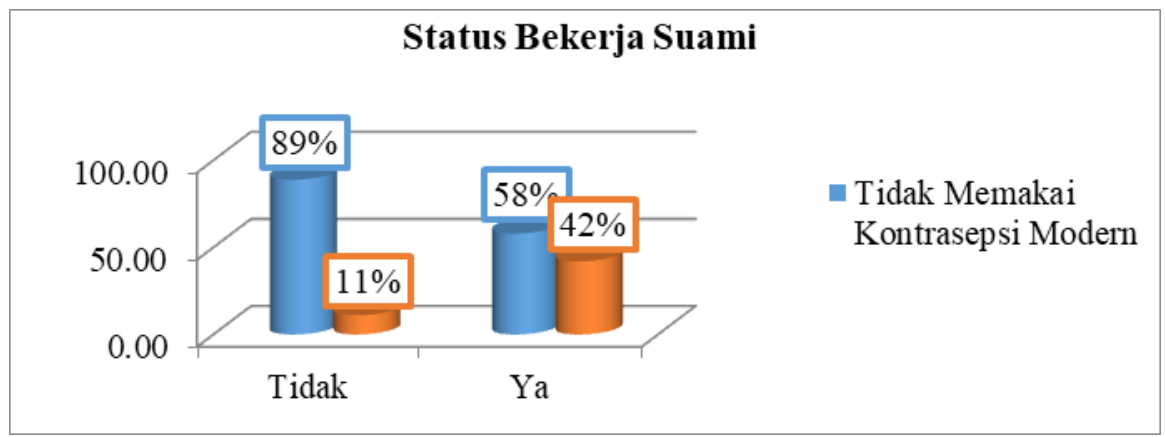

Sumber : SDKI 2017 (diolah)

Gambar 9. Persentase WUS kawin yang menggunakan kontrasepsi modern dan tidak menggunakan kontrasepsi modern berdasarkan variabel status bekerja suami

Persentase WUS yang tidak menggunkan kontrasepsi modern lebih besar dibandingkan persentase WUS kawin yang menggunakan kontrasepsi modern baik yang memiliki suami tidak bekerja maupun bekerja. Persentase WUS kawin yang suaminya tidak bekerja dan tidak menggunakan kontrasepsi modern yaitu sebesar 89 persen, sedangkan WUS kawin yang suaminya tidak bekerja dan menggunakan kontrasepsi modern adalah sebesar 11 persen. Lalu persentase WUS kawin yang memiliki suami bekerja dan tidak menggunakan kontrasepsi modern adalah sebesar 58 persen, angka ini lebih kecil dibandingkan WUS kawin yang suaminya tidak bekerja dan tidak menggunakan kontrasepsi modern. Persentase WUS kawin yang memiliki suami yang bekerja dan mengunakan kontrasepsi modern sebesar 42 persen, angka ini lebih besar dibandingkan WUS kawin yang suaminya tidak bekerja dan menggunkan kontrasepsi modern.

\section{Kunjungan Petugas KB}

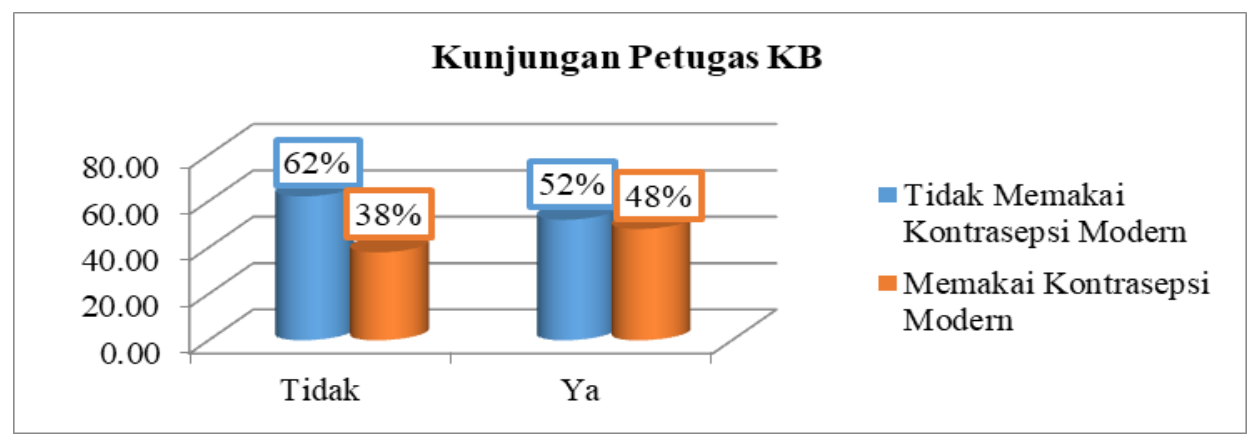

Sumber : SDKI 2017 (diolah)

Gambar 10. Persentase WUS kawin yang menggunakan kontrasepsi modern dan tidak menggunakan kontrasepsi modern berdasarkan variabel kunjungan petugas KB

Persentase WUS yang tidak menggunkan kontrasepsi modern lebih besar dibandingkan persentase WUS kawin yang menggunakan kontrasepsi modern baik yang tidak mendapat 
kunjungan petugas KB maupun yang mendapat kunjungan petugas KB. Persentase WUS kawin yang tidak mendapat kunjungan petugas KB dan tidak menggunakan kontrasepsi modern yaitu sebesar 62 persen, sedangkan WUS kawin yang tidak mendapat kunjungan petugas KB dan menggunakan kontrasepsi modern adalah sebesar 38 persen. Lalu persentase WUS kawin yang mendapat kunjungan petugas KB dan tidak menggunakan kontrasepsi modern adalah sebesar 52 persen, angka ini lebih kecil dibandingkan WUS kawin yang tidak mendapat kunjungan petugas KB dan tidak menggunakan kontrasepsi modern. Persentase WUS kawin yang mendapat kunjungan petugas KB dan mengunakan kontrasepsi modern sebesar 48 persen, angka ini lebih besar dibandingkan persentase WUS kawin yang tidak mendapat kunjungan petugas KB dan menggunkan kontrasepsi modern.

\section{Indeks Kekayaan}

Pada variabel indeks kekayaan, dibagi menjadi tiga kategori yaitu bawah, menengah, dan, atas.

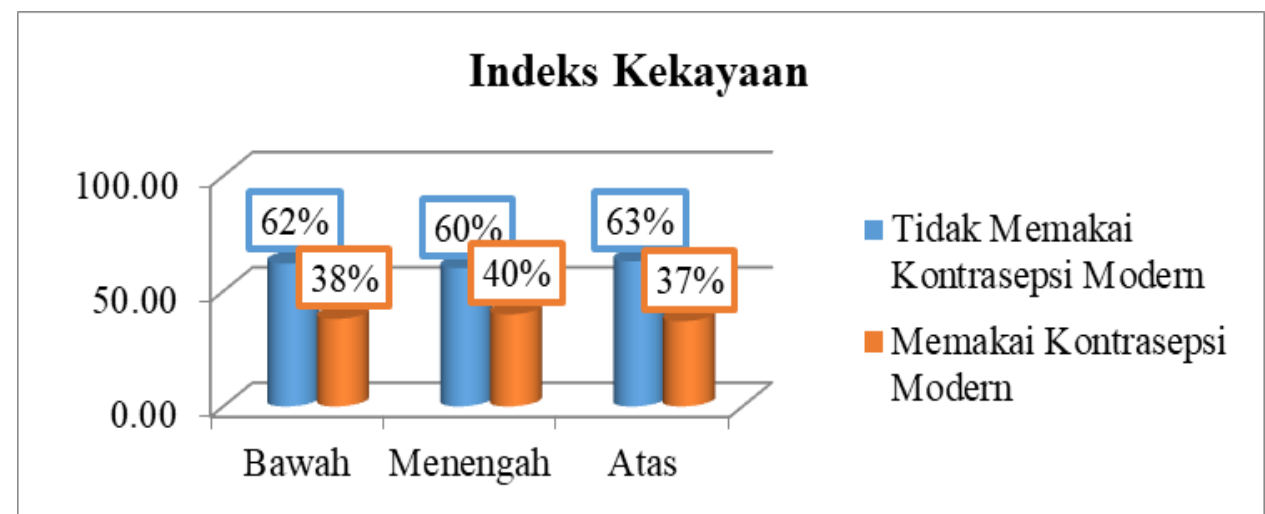

Sumber : SDKI 2017 (diolah)

Gambar 11. Persentase WUS kawin yang menggunakan kontrasepsi modern dan tidak menggunakan kontrasepsi modern berdasarkan variabel Indeks Kekayaan

Persentase WUS kawin yang tidak menggunakan kontrasepsi modern memiliki persentase yang lebih besar dibandingkan WUS kawin yang menggunakan kontrasepsi modern disetiap kategori indeks kekayaan baik dibawah, menengah, dan diatas. Persentase WUS kawin yang memiliki indeks kekayaan dibawah dan tidak menggunakan kontrasepsi modern yaitu sebesar 62 persen, sedangkan WUS kawin yang memiliki indeks kekayaan dibawah dan menggunakan kontrasepsi modern sebesar 38 persen. Lalu persentase WUS kawin yang memiliki indeks kekayaan menegah dan tidak menggunakan kontrasepsi modern adalah sebesar 60 persen, sedangkan WUS kawin yang memiliki indeks kekayaan menegah dan menggunakan kontrasepsi modern sebesar 40 persen. Persentase WUS kawin yang memiliki indeks kekayaan diatas dan tidak menggunakan kontrasepsi modern adalah sebesar 63 persen, sedangkan WUS kawin yang memiliki indeks kekayaan diatas keatas dan menggunakan kontrasepsi modern sebesar 37 persen.

\section{Hasil Analisis Regresi Logistik Biner}

Setelah melakukan pengujian menggunakan SPSS 25, maka diperoleh persamaan regresi logistic sebagai berikut:

$$
\begin{array}{ccccccc}
(D)=-3,174+0,140 & 0,248 & +0,492 & -0,254 & +0,140 & +0,801 & +0,429
\end{array}+
$$

Dimana : 
: variabel dummy umur wanita kawin kategori 25-34

: variabel dummy umur wanita kawin kategori 35-49

: variabel dummy jumlah anak hidup

: variabel dummy jumlah anak ideal

: variabel dummy daerah tempat tinggal

: variabel dummy pendidikan wanita kawin kategori SD-SMP

: variabel dummy pendidikan wanita kawin kategori $\geq S M A$

: variabel dummy status bekerja

: variabel dummy pendidikan suami kategori SD-SMP

: variabel dummy pendidikan suami kategori $\geq$ SMA

: variabel dummy status bekerja suami

: variabel dummy kunjungan petugas KB

: variabel dummy indeks kekayaan wanita kawin ketegori menengah

: variabel dummy indeks kekayaan wanita kawin ketegori atas

Untuk mengetahui bahwa model yang kita peroleh apakah sesuai dalam menjelaskan penggunaan kontrasepsi modern bagi WUS kawin maka dilakukan Uji Hosmer and Lemeshow Goodness of Fit. Sehingga diperoleh nilai pengujiaannya sebesar 14,640 dengan $p$-value (signifikasi) sebesar 0,067. P-value yang didapat lebih besar dari tingkat signifikasi yang dipakai yaitu sebesar 0,05. Sehingga keputusan yang diambil adalah gagal tolak . Maka model yang dipakai untuk menjelaskan penggunaan kontrasepsi modern dalam penilitian layak untuk digunakan.

Untuk mengetahui apakah variabel bebas (umur, jumlah anak hidup, jumlah anak ideal, daerah tempat tinggal, pendidikan, status bekerja, pendidikan suami, status bekerja suami, kunjungan petugas $\mathrm{KB}$, dan indeks kekayaan) yang digunakan secara bersama-sama mempengaruhi secara signifikan variabel terikat (penggunaan kontrasepsi modern oleh WUS kawin). Maka dilakukan pengujian simultan dengan uji rasio likelihood (uji G). hasil uji simultan (Omnibus Tests of Model Coefficients). Sehingga diperoleh nilai uji G sebesar 335,203 dan $p$-value (signifikasi ) sebesar 0,000. P-value yang didapat lebih kecil dari tingkat signifikasi yang dipakai yaitu sebesar 0,05 . Sehingga keputusan yang diambil adalah tolak . Maka berarti dengan tingkat kepercayaan 95 persen minimal ada satu variabel bebas (umur, jumlah anak hidup, jumlah anak ideal, daerah tempat tinggal, pendidikan, status bekerja, pendidikan suami, status bekerja suami, kunjungan petugas $\mathrm{KB}$, dan indeks kekayaan) yang berpengaruh secara signifikan terhadap variabel terikat (penggunaan kontrasepsi modern oleh WUS kawin) atau juga variabel bebas secara bersama-sama mempengaruhi variabel terikat. Sehinnga kemudian dapat dilakukan uji parsial.

Setelah mendapatkan hasil tolah pada uji simultan, selanjutnya dilakukan dengan melakukan uji parsial. Uji parsial itu sendiri digunkan untuk mengetahui variabel yang mana saja 
yang berpengaruh secara signifikan terhadap variabel terikat. Variabel bebas dikatakan mempengaruhi variabel terikat secara signifikan, apabila memiliki nilai $p$-value (signifikasi ) kurang dari tingkat signifikasi yang dipakai yaitu sebesar 0,05 . Berikut tabel yang menjelaskan mengenai uji parsial.

Tabel 1. Hasil Uji Parsial dan odds rasio

\begin{tabular}{|c|c|c|c|c|c|}
\hline Variabel & & S.E & Wald & $p$-value & $\operatorname{Exp}($ ) \\
\hline (1) & (2) & (3) & (4) & (5) & (6) \\
\hline \multicolumn{6}{|l|}{ Umur } \\
\hline \multicolumn{6}{|l|}{$15-24$ (ref) } \\
\hline $25-34$ & 0,140 & 0,104 & 1,815 & 0,178 & 1,150 \\
\hline $35-49$ & 0,248 & 0,109 & 5,191 & 0,023 & 0,780 \\
\hline \multicolumn{6}{|l|}{ Jumlah Anak Hidup } \\
\hline \multicolumn{6}{|l|}{$0-2$ (ref) } \\
\hline$>2$ & 0,492 & 0,082 & 36,146 & 0,000 & 1,635 \\
\hline \multicolumn{6}{|l|}{ Jumlah Anak Ideal } \\
\hline \multicolumn{6}{|l|}{$0-2$ (ref) } \\
\hline$>2$ & 0,254 & 0,067 & 14,209 & 0,000 & 0,776 \\
\hline \multicolumn{6}{|l|}{$\begin{array}{l}\text { Daerah Tempat } \\
\text { Tinggal }\end{array}$} \\
\hline \multicolumn{6}{|l|}{ Kota (ref) } \\
\hline Desa & 0,140 & 0,076 & 3,357 & 0,67 & 1,150 \\
\hline \multicolumn{6}{|l|}{ Pendidikan } \\
\hline \multicolumn{6}{|l|}{ Tidak Sekolah (ref) } \\
\hline Sd-Smp & 0,801 & 0,188 & 18,110 & 0,000 & 2,229 \\
\hline$\geq$ Sma & 0,429 & 0,212 & 4,107 & 0,043 & 1,536 \\
\hline \multicolumn{6}{|l|}{ Status Bekerja } \\
\hline \multicolumn{6}{|l|}{ Tidak (Ref) } \\
\hline Ya & 0,139 & 0,067 & 4,295 & 0,038 & 1,149 \\
\hline Pendidikan Suami & & & & & \\
\hline
\end{tabular}




\begin{tabular}{|c|c|c|c|c|c|}
\hline \multicolumn{6}{|c|}{ Tidak Sekolah (ref) } \\
\hline Sd-Smp & 0,782 & 0,165 & 22,555 & 0,000 & 2,186 \\
\hline$\geq$ Sma & 0,632 & 0,190 & 11,117 & 0,001 & 1,881 \\
\hline \multicolumn{6}{|c|}{$\begin{array}{l}\text { Status Bekerja } \\
\text { Suami }\end{array}$} \\
\hline \multicolumn{6}{|l|}{ Tidak (ref) } \\
\hline Ya & 1,222 & 0,182 & 45,040 & 0,000 & 3,394 \\
\hline \multicolumn{6}{|c|}{$\begin{array}{l}\text { Kunjungan Petugas } \\
\text { KB }\end{array}$} \\
\hline \multicolumn{6}{|l|}{ Tidak (ref) } \\
\hline Ya & 0,303 & 0,148 & 4,182 & 0,041 & 1,354 \\
\hline \multicolumn{6}{|c|}{ Indeks Kekayaan } \\
\hline \multicolumn{6}{|l|}{ Bawah (ref) } \\
\hline Menengah & 0,158 & 0,108 & 2,131 & 0,144 & 1,171 \\
\hline Atas & 0,075 & 0,108 & 0,478 & 0,489 & 1,078 \\
\hline Konstanta & 3,174 & 0,260 & 148,939 & 0,000 & 0,042 \\
\hline
\end{tabular}

Sumber : SDKI 2017(diolah)

Tabel 1 ,dapat dilihat bahwa terdapat beberapa variabel bebas yang memiliki nilai $p$-value (signifikasi ) yang lebih kecil dari tingkat signifikasi yang dipakai yaitu sebesar 0,05. Yang diantaranya umur 35-49 tahun, jumlah anak hidup, jumlah anak ideal, pendidikan, status bekerja, pendidikan suami, status bekerja suami, dan kunjungan petugas KB. Sehingga variabel-variabel tersebut yang secara signifikan mempenaruhi penggunaan kontrasepsi modern oleh WUS kawin di lima provinsi KTI. Sedangkan variabel bebas yang memiliki nilai $p$-value (signifikasi ) yang lebih besar dari tingkat signifikasi 0,05 adalah umur 25-34, daerah tempat tinggal, dan indeks kekayaan. Yang berarti bahwa variabel-variabel tersebut tidak berpengaruh secara signifikan dalam penggunaan kontrasepsi modern oleh WUS kawin di lima provinsi KTI.

\section{KESIMPULAN}

Persentase penggunaan kontrasepsi modern oleh WUS kawin di lima provinsi di KTI sebesar 38 persen. Dan, wanita dengan umur 25 sampai 34 tahun, jumlah anak hidup lebih dari dua, menginginkan jumlah anak maksimal dua anak, pendidikan SD, bekerja, pendidikan suami SD, suami yang bekerja, dan mendapat kunjungan petugas KB memiliki hubungan yang signifikan dengan partisispasi penggunaan kontrasepsi modern. Variabel bebas yang mempengaruhi penggunaan kontrasepsi oleh WUS kawin di lima provinsi di KTI adalah umur, jumlah anak hidup, 
jumlah anak ideal, pendidikan, status bekerja, pendidikan suami, status bekerja suami, dan kunjungan petugas KB. WUS kawin dengan umur 25 sampai 34 tahun, jumlah anak hidup lebih dari dua, menginginkan jumlah anak maksimal dua anak, pendidikan SD sampai SMP, bekerja, pendidikan suami SD sampai SMP, suami yang bekerja, dan mendapat kunjungan petugas KB cenderung menggunakan kontrasepsi modern.

\section{DAFTAR PUSTAKA}

Aryati , S., Sukandi. \& Widyastuti. (2009). Faktor-Faktor yang mempengaruhi Pemilihan Metode Kontrasepsi (Kasus di Kecamatan Seberang Ulu I Kota Palembang). Yogyakarta: Universitas Gajah Mada

Badan Kependudukan dan Keluarga Berencana Nasional. (2011). Kamus Istilah Kependudukan dan Keluarga Berencana. Jakarta: BKKBN.

Badan Kependudukan dan Keluarga Berencana Nasional. (2011). Kebijakan Penyediaan Alat dan Obat Kotrasepsi Gratis dalam Pelayanan Keluarga Berencana bagi Semua Pasangan Usia Subur di Provinsi Aceh, Maluku, Maluku Utara, NTT, Papua, dan Papua Barat. Jakarta: BKKBN.

Badan Kependudukan dan Keluarga Berencana Nasional. (2011). Peraturan Kepala Badan Kependudukan dan Keluarga Berencana Nasional Nomor 78/PER/E3/2011 tentang Penyediaan Alat dan Obat Kontrasepsi Gratis dalam Pelayanan Keluarga Berencana bagi semua Pasangan Usia Subur di daerah Provinsi. Jakarta: BKKBN.

Badan Kependudukan dan Keluarga Berencana Nasional. (2015). Buku Saku Materi Bantu Penyuluhan Kependudukan, Keluarga Berencana dan Pembangunan Keluarga. Jakarta: BKKBN.

Badan Kependudukan dan Keluarga Berencana Nasional. (2016). Laporan Kinerja Instansi Pemerintah 2015 Badan Kependudukan dan Keluarga Berencana Nasional. Jakarta: BKKBN.

Badan Kependudukan dan Keluarga Berencana Nasional. (2018). Jurnal Keluarga Informasi Kependudukan, KB, dan Pembangunan Keluarga. Jakarta: BKKBN.

Badan Pusat Statistik. (2016). Profil Penduduk Indonesia Hasil SUPAS 2015. Jakarta: BPS.

Badan Pusat Statistik. (2018). Survei Demografi dan Kesehatan Indonesia (SDKI) 2017. Jakarta: BPS.

Bertrand, J. (1980). Audience Research for Improving Family Planning Comunication Program, Communication Laboratory Community \& Family Studi Center. USA: University of Chicago.

Bradley, S. E. K., Croft, t.n., Fishel, J.D., \& Westoff,C. F. (2012). Revising Unmet Need for Family Planinng. DHS Analytical Studies No. 25. USA:ICF International.

Dewan Perwakilan Rakyat. (2009). Kesehatan. Jakarta: DPR.

Hartanto, H. (2004). Keluarga Berencana dan Kontrasepsi. Jakarta: Pustaka Sinar Harapan.

Kementerian Kesehatan. (2013). Situasi Keluarga Berencana di Indonesia. Jakarta: kemenkes.

Manortey, S. \& Lotsu, P. (2017). Factors Affecting Contraceptive Use among Reproductive Aged Women: A Case Study in Worawora Township, Ghana. Ghana: Ensign College of Public Health, Kpong, Eastern Region, Ghana.

Palamuleni, M.E. (2013). Socio-Economic and Demographic Factors Affecting Contraceptive use in Malawi. African Journal of Reproductive Health September 2013; 17(3), 91 - 104.

RI (Republik Indonesia). (2009). Undang-undang nomor 36 tahun 2009 tentang kesehatan. Sekertariat Negara. Jakarta.

Shaw. (2010). The $A B C$ 's of Family Planing.

Suratun, S. M., Hartini, T., \& Rusmiati, S. P. (2008). Pelayanan Keluarga Berencana dan Pelayanan Kontrasepsi. Jakarta: Trans Info Media.

United NATIONS. (1995). Report of International Conference on Ppopulation and Development (ICPD). United Nations, Sales No. 95.XIII.18, A/CONF.17/13/Rev.1, ISBN 92-1-151289-1. 